\title{
Implementing Lean Manufacturing in High-mix Production Environment
}

\author{
Remigiusz Horbal ${ }^{1}$, Robert Kagan ${ }^{1}$, Tomasz Koch ${ }^{1}$ \\ 1 Center for Advanced Manufacturing Technologies (CAMT), Institute of \\ Production Engineering and Automation, Wroclaw University of \\ Technology \\ ul. Lukasiewicza 5, 50-370 Wroclaw, Poland \\ WWW home page: www.pwr.wroc.pl, www.lean.org.pl
}

\begin{abstract}
Lean Manufacturing concept is well described in the literature in the context of low-mix high-volume production. There are numerous case studies proving outstanding benefits of implementation Lean principles. Nowadays enterprises have to face the problem of high variety of products and dynamically changing demand. Lean tools and methods known from repetitive production do not always fit to high-mix environment. It causes problems with proper design of one-piece-flow production cells and material flow based on pull system. The purpose of the paper is to present a case study of implementing Lean concept in the enterprise producing high-mix of industrial fittings.
\end{abstract}

\section{Introduction}

The chosen enterprise is a leader on the Polish marketplace in industrial fittings producing over 1000 of types of valves used in the processes of liquid and gas flows regulation. The production is made to orders. Demand is irregular and seasonal. Additional obstacle is the fact that products are differentiated in the very first steps of production process. The process typically consists of casting, machining, assembly, testing, cleaning, special treatment and painting. The paper focuses on assembly department reorganization based on Lean approach.

At the very first stage of the project Value Stream Mapping tool [1] has been used to elaborate the current and future state value stream map. Future state map allowed estimating the potential influence of planned reorganization of assembly system on the rest of the production operations and identifying the improvement areas. Based on the future state map the goal for assembly system reorganization has been defined to increase productivity by $20 \%$ with the same resources.

Please use the following format when citing this chapter:

Horbal, R., Kagan, R. and Koch, T., 2008, in IFIP International Federation for Information Processing, Volume 257, Lean Business Systems and Beyond, Tomasz Koch, ed.; (Boston: Springer), pp. 257-267. 
During the first observations it was noticed that assembly operators' work content contains significant amount of non value adding activities such as e.g. waiting for parts, reaching for parts and tools, moving within the workplace. It was decided that elimination of non value adding steps from work content is crucial to achieve the determined goal of the project. To fulfill that following lean tools were identified to apply:

T1. One-piece-flow to reduce WIP level within workplace and shorten lead time.

T2. Standardized work to reduce variability of assembly cycle time for given product type.

T3. Proper material presentation at the workplace to reduce reaching for parts and unnecessary movement of operators.

T4. Milk run material delivery system to reduce the level of inventories at the workplaces and prevent operators from leaving workplaces to bring the parts.

T5. Pull based material flow system from machining to assembly to reduce shortages of parts for assembly.

The tools mentioned above were originally suited to low-mix, repetitive production. Their application to the described project required necessary adaptations to specific, high-mix production conditions. All the listed tools T1-T5 could be considered as a combination of conceptual layer (general concept) and technical layer (technical solution). The assumption was made that the general concept may be applied to any type of production but technical solution has to be changed and adapted to specific conditions of high-mix production. The Table 1 presents both conceptual and technical layers of all the mentioned tools T1-T5.

For the case study described in this paper the tools T3-T5 had to be adapted for hig-mix production conditions. Section 2 contains the description of standardized work and material presentation and section 3 milk-run deliveries and pull system suitable for high-mix production.

\section{Implementing one-piece-flow assembly cells}

The first steps on the way to achieve the goals defined on the Future State Value Stream Map and to create a lean assembly system following elements were designed:

- a suitable placement of equipment and assembly workstations,

- appropriate flow routes of parts and subassemblies

- pull system.

The goal was to convert the logic of both information and material flows from the Future State Map into technical specification of the assembly system layout while finding the minimum amount of equipment, materials and people needed to build high-mix of orders. Here very useful lean manufacturing techniques were applied: continuous flow and the method of equipment arrangement into assembly cells. Mentioned tools are described in [2] and [3]. 
Table 1. Conceptual and technical layer of selected lean tools

\begin{tabular}{|l|l|l|l|}
\hline \multicolumn{1}{|c|}{ Tool } & Conceptual layer & $\begin{array}{l}\text { Technical layer for repetitive } \\
\text { production }\end{array}$ & \multicolumn{1}{c|}{ Problems } \\
\hline $\begin{array}{l}\text { T1. One piece } \\
\text { flow }\end{array}$ & $\begin{array}{l}\text { Moving and } \\
\text { processing products } \\
\text { in one piece batches }\end{array}$ & $\begin{array}{l}\text { Product workcell with balanced } \\
\text { operators' work content (every } \\
\text { operator in workcell has almost } \\
\text { the same cycle time) }\end{array}$ & $\begin{array}{l}\text { Balancing of operators' work } \\
\text { according to different work } \\
\text { content for different product } \\
\text { types }\end{array}$ \\
\hline $\begin{array}{l}\text { T2. } \\
\text { Standardized } \\
\text { work }\end{array}$ & $\begin{array}{l}\text { Defining detailed } \\
\text { standards and } \\
\text { procedures for all } \\
\text { operator's work } \\
\text { elements }\end{array}$ & $\begin{array}{l}\text { Formal instruction in graphic } \\
\text { form (usually one page A4) } \\
\text { placed on the workplace }\end{array}$ & $\begin{array}{l}\text { Standardized work varies } \\
\text { according to different } \\
\text { product types }\end{array}$ \\
\hline $\begin{array}{l}\text { T3. Material } \\
\text { presentation }\end{array}$ & $\begin{array}{l}\text { Providing materials } \\
\text { directly to } \\
\text { operators' fingertips }\end{array}$ & $\begin{array}{l}\text { Flow racks with components } \\
\text { placed near to operator's } \\
\text { fingertips }\end{array}$ & $\begin{array}{l}\text { High variety of different } \\
\text { components for different } \\
\text { product types. }\end{array}$ \\
\hline $\begin{array}{l}\text { T4. Milk run } \\
\text { deliveries }\end{array}$ & $\begin{array}{l}\text { Regular and } \\
\text { frequent deliveries } \\
\text { of small amount of } \\
\text { materials according } \\
\text { to defined routine }\end{array}$ & $\begin{array}{l}\text { Material handler provides } \\
\text { frequently variety of } \\
\text { components in small quantities } \\
\text { directly to workcell flow racks } \\
\text { based on kanban signals. } \\
\text { During one course several } \\
\text { workcells are served. }\end{array}$ & $\begin{array}{l}\text { Set of components for } \\
\text { production changes several } \\
\text { times during the shift and } \\
\text { components could not be } \\
\text { replenished according to } \\
\text { typical kanban cards }\end{array}$ \\
\hline $\begin{array}{l}\text { T5. Pull } \\
\text { system }\end{array}$ & $\begin{array}{l}\text { Material flow driven } \\
\text { by signals from next } \\
\text { process instead of } \\
\text { MRP production } \\
\text { schedule }\end{array}$ & $\begin{array}{l}\text { Components are stored in the } \\
\text { supermarket in predefined } \\
\text { quantities and replenished } \\
\text { according to actual } \\
\text { consumption }\end{array}$ & $\begin{array}{l}\text { Replenishment pull system } \\
\text { generates large inventories } \\
\text { for high-mix production }\end{array}$ \\
\hline
\end{tabular}

According to observations made on the shop floor there were a lot of different components, materials and subassemblies stored on the floor around workplaces. It was also noticed that operators spent a significant amount of their time bringing parts from storeroom to the workplaces, searching for materials, reaching for parts and tools. Moreover the production was performed by operators in batches e.g. for 4 hours production. Additional problem observed in high-mix production realised within one workplace was high mix of different component types stored around a workstation.

The idea of organising assembly system in assembly cells was based on assumption that any transport activity as well as any interruption of material continuous flow is waste. The assembly cell arranges assembly equipment and personnel in process sequence and includes all the operations necessary to complete a product or a major assembly sequence. When operations are arranged into cells, operators can produce and transfer parts one piece at the time (one-piece-flow) with improved safety and reduced effort.

There was also assumed that all components and materials should be properly presented to assembly operators and delivered on time and directly to the operators' 
fingertips. To do that the containers with parts and assemblies should be placed on flow racks in point of use within cell.

Figure 1 shows a 3D computer model of proposed and implemented assembly worksation including the flow rack for material presentation. Implementation of such a one-piece-flow solution, where one operator can perform all necessary assembly steps from beginning to the end effected in 50\% reduction of needed production space. Also the efficiency of assembly department was increased by $33 \%$ in average (depend on type of product).

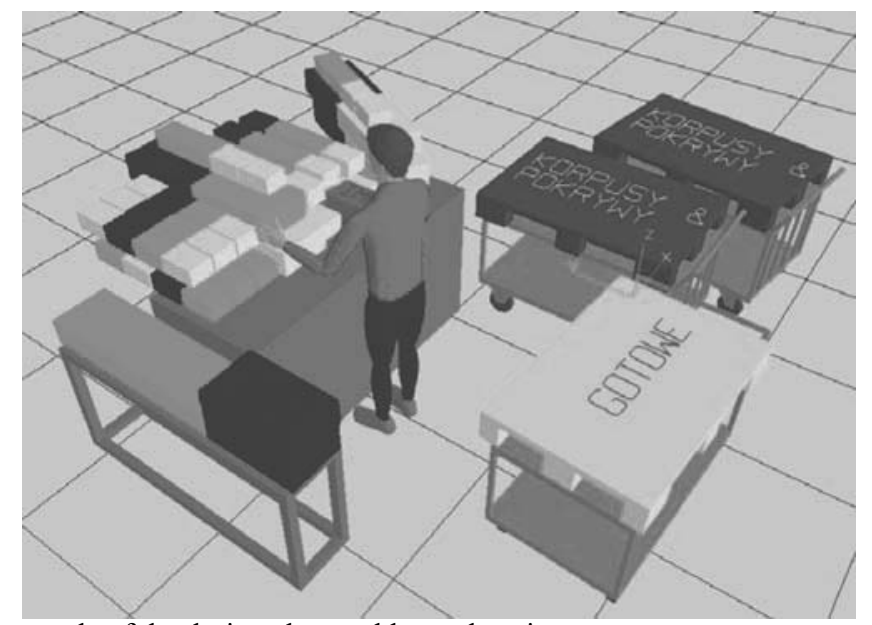

Fig. 1. An example of the designed assembly workstation

\subsection{Standardized work and flexible material presentation}

An important lean tool supporting one-piece-flow production is a standardized work. The standardized work instruction defines in details all work elements performed by operator on assembly station and has usually a graphical, very visual form. A challenge here was to prepare such an instruction for high-mix production workstation in spite of different product types and assembly processes.

To create such a standardized work instruction all types of assembly processes performed on assembly stations were caught on video tape and analyzed. The analysis showed that only $40 \%$ of all operations performed by assembly operators were value-adding operations. The goal here was to define a detailed assembly procedure including only necessary steps to produce one selected product. The effect of those analyses were 25 standardized work instruction cards for 30 different product types assembled on designed workcell. Their implementation caused $10 \%$ improvement on product quality. Figure 2 presents an example of standardized work instruction card. 


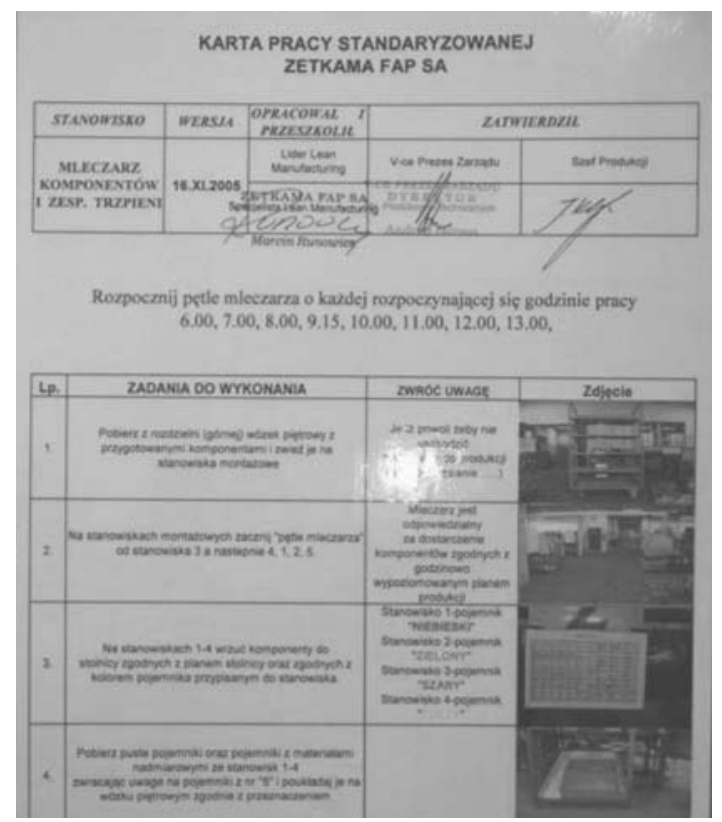

Fig. 2. Standardized work instruction card on workstation

Effective and quick assembly process within the workcell required an effective material delivery system to the operators' fingertips. As already mentioned very important element of this system is, a proper equipment for material presentation a flow rack at parts' point of use. The main goal here is to design such a flow rack which ensures that all parts and assemblies are available for operators without any unnecessary movement and reaching. However, to reach this goal in high-mix production performed on one versatile assembly cell was a real challenge. In described case special analyses were performed and a suitable flow rack designed where all parts are in the best ergonomic location for operator. Because of many different product types produced on the workstation it is needed that parts are delivered to the flow rack in kits prepared for one or two hours of production and placed in dedicated slides on the rack. The rack is able to hold the material for 3 hours of production. Colour coded bins for parts facilitates delivery process managed by material handlers. Figure 3 presents an example of flow rack for assembly station.

\section{Implementing pull system}

The pull system was identified as a crucial tool to decrease the level of inventories and improve the availability of the components for assembly. The components are produced by machining department and provided to the warehousing 
area between machining and assembly departments. The problems to manage these components were typical for companies using ERP systems. Changing customer demand caused frequent changes of daily production plans during the production shift both for assembly and machining departments. Keeping ERP database updated real time required significant work effort or very high (and expensive) automation level of data mining process. In the result ERP production plans and inventory levels recorded in the database quickly after beginning of the shift became invalid and then were corrected once per day. The negative effect of such situation was reasonably high inventory levels ( 8 days) and low availability components for assembly process (only $35 \%$ of components produced internally available on time).

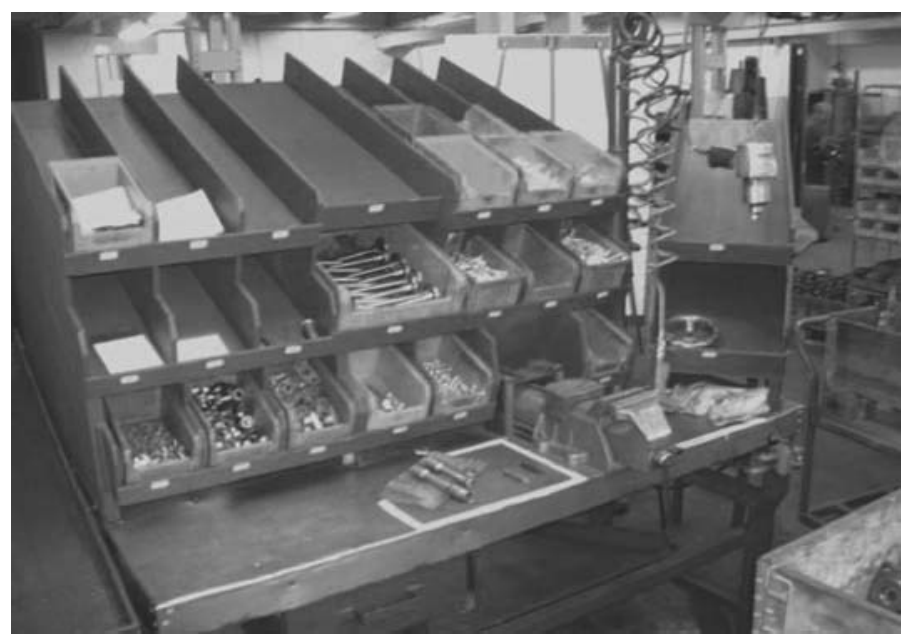

Fig. 3. Flow rack for material presentation within assembly cell

Numerous case studies proves that implementation of leveled pull system allows to avoid frequent changes in production plans and to control inventories on lower level while improving components availability [4][5][6][7]. From the other side all the cited papers concern repeatable production with limited product variants. Considered company produced about 1000 different types of product for individual customres. The pull system was planned to improve material flow from machining to assembly for two main components: bodies and covers in approx. 230 types.

The typical supermarket pull system is shown in the fig. 4. Customer and supplier processes may be the different production processes in the same facility. Supermarket holds every type of components produced by supplier in predefined quantity.

Customer process has always all the types of components available in the supermarket. Supplier process does not use ERP plan to schedule production of components but replenishes what was taken by customer process from the supermarket. In the result supplier process is insensitive for any invalid data in ERP database. Supermarket pull system allows providing right components to the 
customer process on time with reasonably low level of inventories if the components are delivered only in few types and consumption of components is stable.

In the case of considered company typical supermarket pull system was inefficient because demand was not stable and high variety of components was demanded by assembly process. To find proper solution the customer demand was analyzed for every type of components. All the components were divided into three categories: A. High-runners, B. Medium-runners and C. Low-runners. Below in table 2 the characteristics of all the categories have been described.

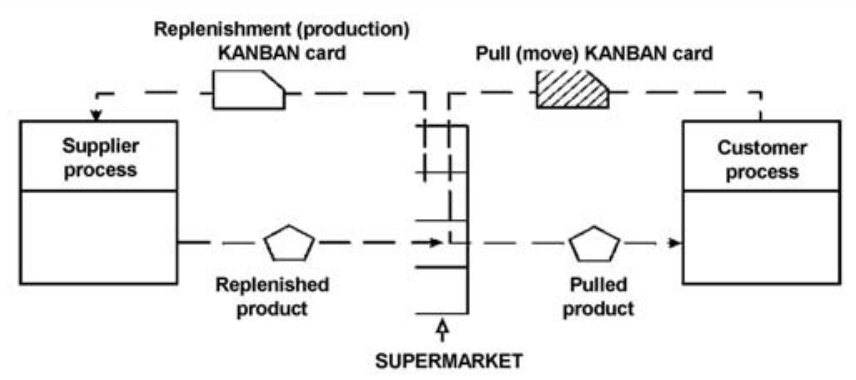

Fig. 4. Flow Typical supermarket (replenishment) pull system [1]

Table 2. Division of the components into $\mathrm{ABC}$ categories according to customer demand

\begin{tabular}{|l|l|}
\hline A. High-runners & $\begin{array}{l}\text { Components for products ordered by most of the customers in large } \\
\text { volumes. The consumption by assembly department repeatable. Average } \\
\text { daily demand for assembly more then 15 pcs. Components consumed in } \\
\text { assembly process irregularly, usually once per week. }\end{array}$ \\
\hline $\begin{array}{l}\text { B. Medium- } \\
\text { runners }\end{array}$ & $\begin{array}{l}\text { Components for products often ordered by the customers. The average } \\
\text { daily consumption lower then for high-runners, among 5-15 pcs. } \\
\text { Components consumed by assembly process once per 2-3 weeks. }\end{array}$ \\
\hline C. Low-runners & $\begin{array}{l}\text { Components ordered rarely or in very low volumes as part of bigger } \\
\text { orders for high- and medium-runners. Components consumed by } \\
\text { assembly process once per several moths. }\end{array}$ \\
\hline
\end{tabular}

$\mathrm{ABC}$ analysis showed that the components defined as high-runners are parts for the products which are ordered by final customers regularly but produced irregularly, usually once per week in big batches of 500 pieces or more. It was decided to implement leveled production plan for high-runner products and to produce them every day in small batches, e.g. 100 pcs every day instead of 500 once per week. In the result these components became to be consumed by assembly in the similar way like components in the repeatable production process. The inventories on hand required for these components were dramatically decreased (in above example from 500 to 100 of pcs).

Medium runners were divided into 2 groups: 
- $\quad$ B1. Components consumed by assembly regularly but rarely,

- $\quad$ B2. Components consumed irregularly in small volumes.

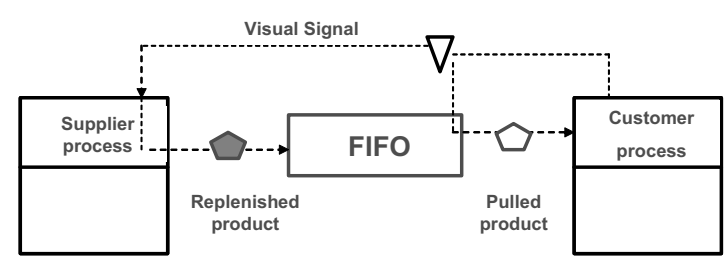

Fig. 5. The sequential (FIFO) pull system

The components of B1 group were designated to assembly once per week (leveled schedule in weekly batches). It was decided that components of B1 group would be hold together with high-runners (A group) in supermarket and controlled by typical supermarket pull system. For components of B2 and C groups the sequential pull system were designed. The main idea of the sequential pull system is shown in the fig. 4 . In this system customer process does not receive any ERP plan but produces the products according to the component FIFO queue set in order by supplier process.

Finally the mixed pull system was installed (see in fig.5). This system contained supermarket pull system for high-runners and medium-runners of B1 group and sequential (FIFO) pull system for low-runners and medium-runners of B2 group.

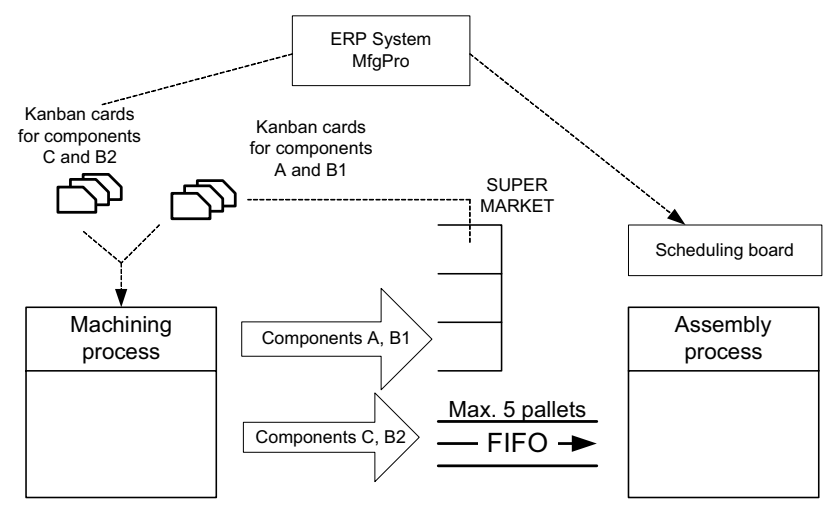

Fig. 6. Mixed pull system

In the result most of the components (A and B1) are produced based on replenishment signals and became insensitive for incorrect data of ERP systems. Additionally thanks to leveled production the frequency of changes of production 
plan for assembly department was reduced. The rest of components (B2 and C) are produced by the machining department according to ERP plan, but then their flow is controlled by FIFO queue (first-in-first-out). The main effort of maintaining ERP system has to be focused on C and B2 components which constitute less then $40 \%$ of production volume.

The result of implementing mixed pull system was improvement the availability of components on time from 35 to $95 \%$ while reducing inventories.

Pull system is usually implemented together with milk-run delivery routes of material handlers. The overall idea of milk-run deliveries is shown in the fig. 6 . Material handler regularly, e.g. every hour, drives his tuger along the standardized route (a milk-run route) and provides components for hourly production to all the workcells placed along the milk-run route. While providing components to the workcells he collects the kanban cards (or empty boxes) which provide information what kind of components and in what quantity need to be provided to the particular workcell during the next milk-run. Milk-run deliveries are efficient method to keep inventories on the shop floor on very low level and to increase material handler productivity. This scheme works perfectly for repetitive production, where the same types of components are used for longer period.

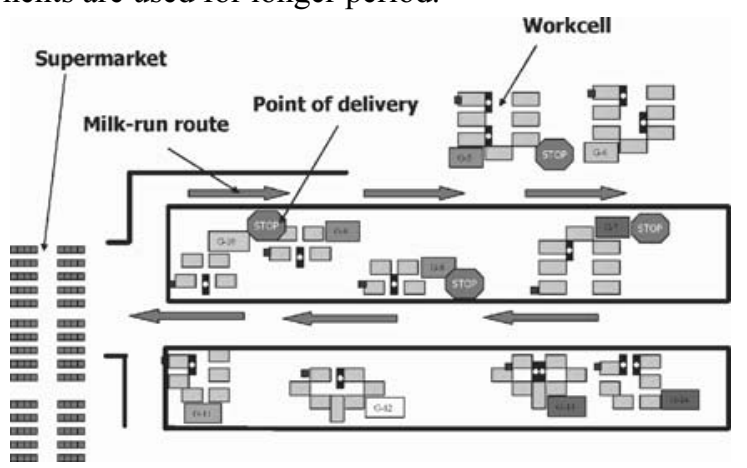

Fig. 7. Milk-run deliveries of components to production workcells

After implementing leveled production in small batches of variety of products in the considered company, every hour the different type of product is produced and different set of components is required. That is why kanban cards can not be used to provide material handlers with the information what components deliver to the workcells during the next milk-run. To resolve this problem the final product kanban cards were implemented instead of components kanban cards. This method is shown in the fig. 7. Material handler during each milk run delivers components to the workcells for 2 hours of production and takes final product kanban cards for the next 2 hours from scheduling board. Then he provides these cards to the component supermarket. Product kanban card holds information about the whole set of components required to assembly the given final product. Thanks to this information material handler knows what components pick up for the next milk run. 


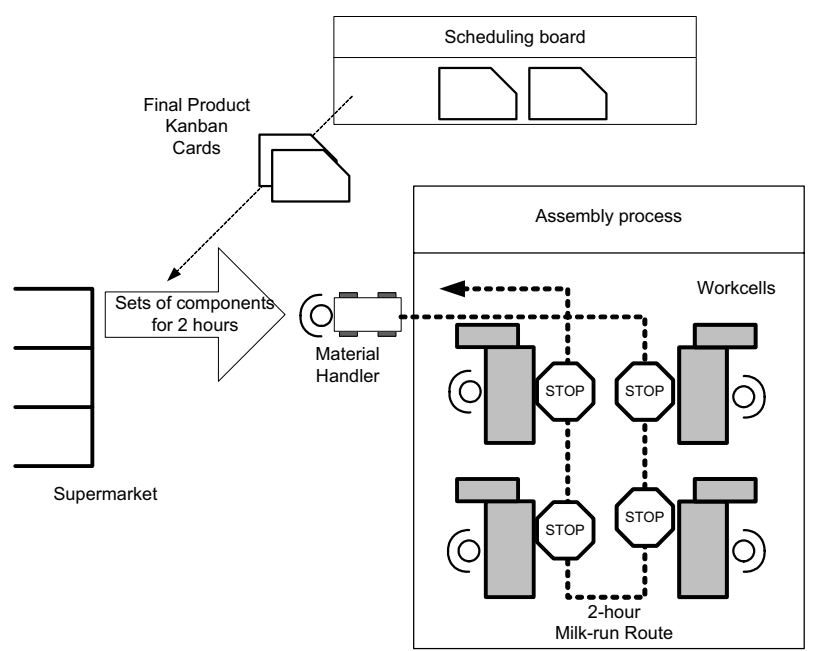

Fig. 8. Final product kanban cards provide information on what set of components provide to the workcells during the next milk-run

During the next milk-run the set of components together with product kanban card is provided to the workcell. After implementing milk-run delivery system the level of inventories on the shopfloor was reduced to 2 hours and the space required for production was reduced by approx. $50 \%$.

\section{Conclusions}

The lean concept can be applied successfully in high-mix production environment however the lean management tools have to be modified on the level of technical solution for high-mix constraints. The proposed lean tools such as flexible parts presentation, milk-run deliveries and mixed pull system allowed to improve productivity of assembly department in the analyzed enterprise by $33 \%$ and to reduce space required for assembly by $50 \%$. In table 3 the required adaptations are briefly described. 
Table 3. Adaptations of selected lean tools for high-mix production

\begin{tabular}{|l|l|l|}
\hline \multicolumn{1}{|c|}{ Tool } & \multicolumn{1}{|c|}{$\begin{array}{c}\text { Technical layer for repetitive } \\
\text { production }\end{array}$} & \multicolumn{1}{c|}{ Technical layer for high-mix production } \\
\hline $\begin{array}{l}\text { T3. Material } \\
\text { presentation }\end{array}$ & $\begin{array}{l}\text { Flow racks with components placed } \\
\text { near to operator's fingertips. }\end{array}$ & $\begin{array}{l}\text { Flexible material presentation } \\
\text { Assignment of components to the flow racks } \\
\text { shelves changes during production shift } \\
\text { according to different product types. }\end{array}$ \\
\hline $\begin{array}{l}\text { T4. Milk run } \\
\text { deliveries }\end{array}$ & $\begin{array}{l}\text { Material handler provides frequently } \\
\text { variety of components in small } \\
\text { quantities directly to workcell flow } \\
\text { racks based on kanban signals. During } \\
\text { one course several workcells are } \\
\text { served. }\end{array}$ & $\begin{array}{l}\text { Sequential milk run deliveries } \\
\text { Kanban signals provide information about } \\
\text { necessity of components delivery but not the } \\
\text { type of component required. The type of } \\
\text { needed components is obtained from next } 4- \\
\text { hour production schedule. }\end{array}$ \\
\hline $\begin{array}{l}\text { T5. Pull } \\
\text { system }\end{array}$ & $\begin{array}{l}\text { Components are stored in the } \\
\text { supermarket in predefined quantities } \\
\text { and replenished according to actual } \\
\text { consumption. }\end{array}$ & $\begin{array}{l}\text { Mixed pull system } \\
\text { Components divided into ABC categories } \\
\text { according to pace of consumption. Different } \\
\text { types of pull system applied to different } \\
\text { categories, e.g. replenishment pull system for } \\
\text { high-runners, sequential pull system for low- } \\
\text { runners. }\end{array}$ \\
\hline
\end{tabular}

\section{References}

1. Rother M., Shook J.: Learning to see - value stream mapping to create value and eliminate muda. The Lean Enterprise Institute. Brooklin Massachusetts, 1999.

2. Rother, M., Harris, R., Creating Continuous Flow, The Lean Enterprise Institute. Brooklin Massachusetts 2001.

3. Harris, R., Harris, Ch., Wilson, E., Making Materials Flow, The Lean Enterprise Institute. Brooklin Massachusetts 2003.

4. Shingo, S., A study of Toyota Production System, Productivity Press, Oregon USA, 1989.

5. Wójcik, K., Sawicz, P., Implementing pull system and continuous flow in the company Inter Mind, Proceedings V Lean Manufacturing Conference, Wroclaw Centre for Technology Transfer WCTT, Wroclaw 2005.

6. Szostak, J., Bielewski, A., Delco Remy Poland - Implementing continuous flow, Proceedings IV Lean Manufacturing Conference, Wroclaw Centre for Technology Transfer WCTT, Wroclaw 2004.

7. Horbal, R., Koch, T.: From supplier to production line - lean approach for purchased material flow. Systems 2005 vol. 10 no 1 with Appendix pp. 81-88, Wroclaw 2005. 